\title{
Impact of Deposition Rate on the Structural, Optical, and Electrical Properties of Zinc Oxide (ZnO) Thin Films Prepared by Solar Spray Pyrolysis Method
}

\author{
Bedreddine Maaoui ${ }^{1,2}$, Yacine Aoun ${ }^{2}$, and Said Benramache ${ }^{3}$ \\ ${ }^{1}$ VTRS Laboratory, Faculty of Technology, \\ University of El-Oued, \\ 39000 El-Oued, Algeria \\ ${ }^{2}$ Mechanical Department, Faculty of Technology, \\ University of El-Oued, \\ 39000 El-Oued, Algeria \\ ${ }^{3}$ Material Sciences Department, Faculty of Science, \\ University of Biskra, \\ 07000 Biskra, Algeria
}

In the present research, thin films of zinc oxide $(\mathrm{ZnO})$ are elaborated by solar spay pyrolysis method with using solar energy to heat glass substrate at $450^{\circ} \mathrm{C}$ in ambient atmosphere without any special conditions. This method was developed in our laboratory using simple tools. The zinc acetate with a molarity of $0.1 \mathrm{M}$ was sprayed with deferent deposition rates $(7,11$ and $13 \mathrm{ml})$. The effect of such depositions on the structural, optical, and electrical properties is examined by using x-ray diffraction (XRD), ultraviolet and visible spectroscopy, and four-point probe method, respectively. The analysis of properties shows that $\mathrm{ZnO}$ films are polycrystalline with the preferential orientation (002) and are crystallized in the wurtzite-phase type. The grain size increases to $23 \mathrm{~nm}$, then decreases until it reaches $16 \mathrm{~nm}$. The direct band-gap value decreases from 3.30 to $3.28 \mathrm{eV}$, when the thickness increases from 126 to $148 \mathrm{~nm}$. As revealed, the conductivity varies with film thickness.

У цьому дослідженні тонкі плівки оксиду цинку (ZnO) були розроблені методою сонячної піролізи пульверизованого шару - за допомогою використання сонячної енергії для нагрівання скляної підкладинки за температури у $450^{\circ} \mathrm{C}$ у атмосфері навколишнього середовища без жодних особливих умов. Цю методу було розроблено в нашій лабораторії за допомогою простих інструментів. Ацетат цинку з молярністю у 0,1 M розпорошували за різних швидкостей осадження (7, 11 і 13 мл). Вплив таких осаджень на структурні, оптичні й електричні властивості дослі- 
джували за допомогою рентґенівської дифракції (XRD), ультрафіолетової та видимої спектроскопії та чотироточкової зондової методи відповідно. Аналіза властивостей показує, що плівки $\mathrm{ZnO} є$ полікристалічними з переважною орієнтацією (002) та кристалізуються у фазі вюртцитового типу. Розмір зерна збільшується до 23 нм, потім зменшується до досягнення 16 нм. Величина забороненої енергетичної зони з прямими переходами зменшується від 3,30 до 3,28 еВ, коли товщина збільшується від 126 до 148 нм. Виявлена електропровідність змінюється залежно від товщини плівки.

Key words: $\mathrm{ZnO}$, thin films, deposition rate, solar spray pyrolysis technique.

Ключові слова: $\mathrm{ZnO}$, тонкі плівки, швидкість осадження, методика сонячної піролізи пульверизованого шару.

(Received 24 March, 2020)

\section{INTRODUCTION}

Zinc oxide (ZnO), which is one of the most important II-VI semiconductor materials, is semiconductor with a wide direct energy band gap of $3.37 \mathrm{eV}$ [1]. At room temperature, $\mathrm{ZnO}$ has a hexagonal wurtzite-type structure and a natural $n$-type electrical conductivity; whereby changing the annealing conditions and doping, the resistivity may be adjusted by order of magnitude to $10^{-4} \mathrm{Ohm} \cdot \mathrm{cm}$ [2]. Recently, $\mathrm{ZnO}$ takes some important part of researching, because it has high chemical and mechanical stability that allows it to be used in photovoltaic cells [3]; his wide direct band gap makes it transparent for a large wavelength range in the solar spectrum [4]; $\mathrm{ZnO}$ has considerable thermal stability in hydrogen plasma atmosphere, low electrical resistivity [5], and low cost price. All these properties make it the most important transparent conducting oxides [6] (TCO). Several deposition techniques have been widely used to produce TCO films, namely, RF magnetron sputtering [7], molecular beam epitaxy (MBE) [5], reactive thermal evaporation [8], pulsed laser deposition (PLD) [9], chemical vapour deposition [10], electrochemical deposition and spray pyrolysis technique (SPT) [11]. Among these methods, spray pyrolysis has many advantages to allow it to be the most appropriate technique for producing thin films such as simpler and inexpensive one and taking a hand to obtain films with the efficient properties for optoelectronic applications.

In this work, we deposited thin $\mathrm{ZnO}$ films on glass substrate, using solar spray pyrolysis technique, and we have studied the impact of deposition rate on the structural, optical, and electrical properties of thin $\mathrm{ZnO}$ films. The main goal for this research is to find 
optimum information on deposition rates, which give reliable properties, and use renewable energy such as solar energy to produce semiconductors.

\section{EXPERIMENTAL}

The spray pyrolysis technique permits to obtain thin films of metal oxides with the required properties, as it is the case for the $\mathrm{ZnO}$ material. In this method, the solution precursor was prepared by dissolving $0.1 \mathrm{M}\left(\mathrm{Zn}\left(\mathrm{CH}_{3} \mathrm{COO}\right)_{2}, 2 \mathrm{H}_{2} \mathrm{O}\right)$ in deionised water. To stabilize and acquire transparent solution, we have added a few drops of concentrated hydrochloric acid $(\mathrm{HCl})$ and stirred the mixture at $60^{\circ} \mathrm{C}$ for $120 \mathrm{~min}$. Before started spraying the solution, we had taken R217102 glass with $30 \mathrm{~cm} \times 7.5 \mathrm{~cm} \times 0.1 \mathrm{~cm}$ as substrate and cleaned it. To heat the substrates, we had used the solar cells' method, wherever, we have fabricated solar parabolic concentrator as shown in Fig. 1; the sun rays fall on a mirror coated parabolic surface (reflector), reflecting toward the area where the substrates are placed (receiver). When $\mathrm{Zn}$ precursors sprayed over a hot substrates glass, a pyrolytic process occurred, and $\mathrm{ZnO}$ films were produced. The possible reaction proposed by Paraguay et al. [12] is as follows:

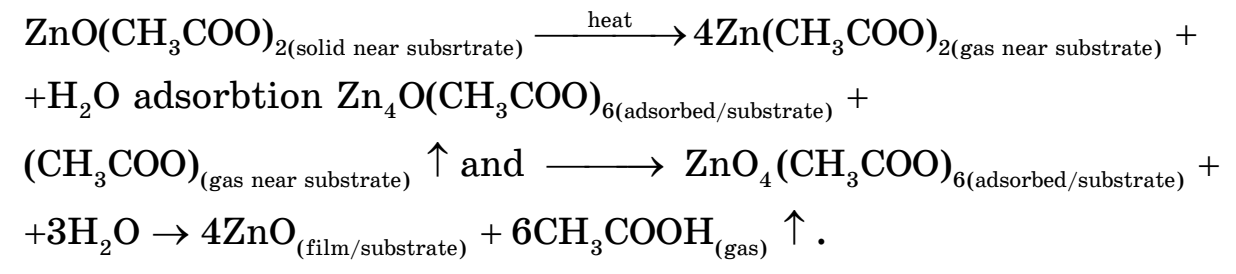

The Bruker AXS-8D diffractometer with $\mathrm{Cu} K_{\alpha}$ radiation $(\lambda=$ $=0.15406 \mathrm{~nm}$ ) was employed to record the XRD pattern of the de-

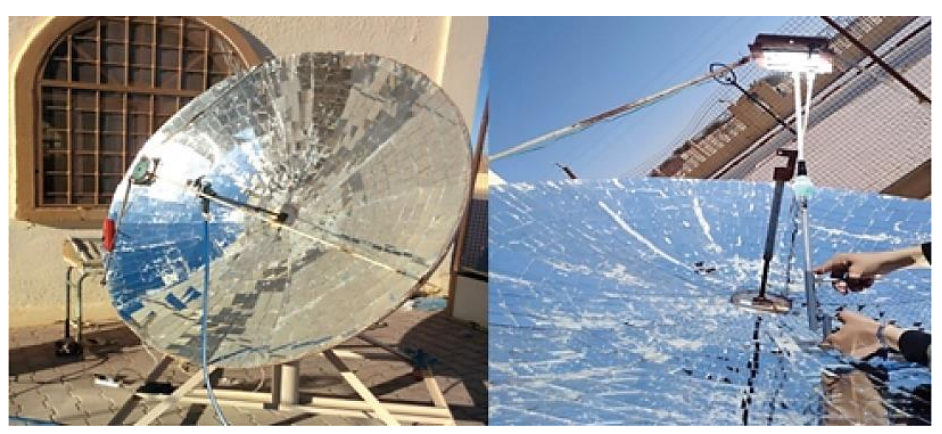

Fig. 1. The experimental setup. 
posited thin $\mathrm{ZnO}$ films. The optical transmittance of the as-prepared thin $\mathrm{ZnO}$ films was recorded in the range of $300-900 \mathrm{~nm}$ by an ultraviolet-visible spectrophotometer (SHUMADZU UV-1800). Finally, the electrical resistivity of the resulting films were investigated using four-probe methods with Keithley 2400-LV Low Voltage SourceMeter instrument at the room temperature.

\section{RESULTS AND DISCUSSION}

\subsection{Crystal Structure of Thin ZnO Films}

The x-ray diffraction patterns of the solar spray-deposited thin $\mathrm{ZnO}$ films are shown in Fig. 2. As can be noticed, there are seven obvious peaks corresponding to (100), (002), (101), (102), (110), (103) and (112) planes. The XRD spectrum shows well that all films are

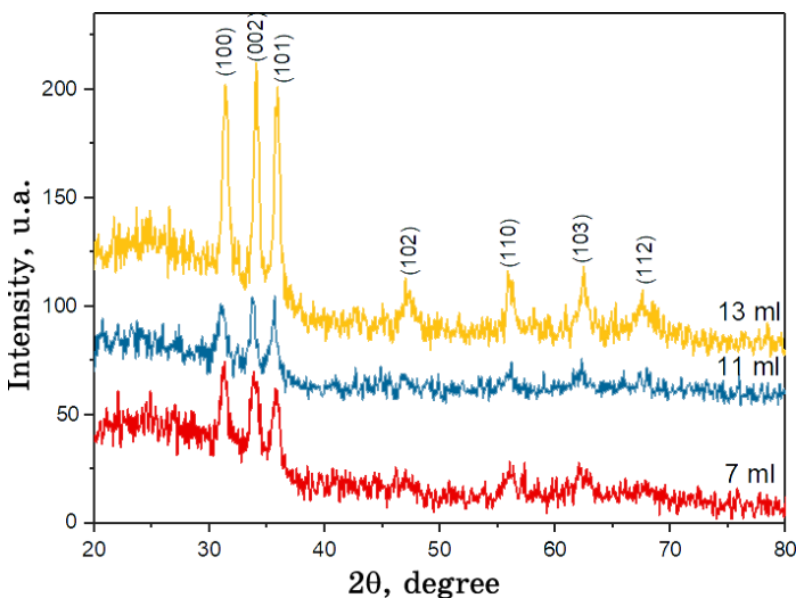

Fig. 2. X-ray diffraction spectra of thin $\mathrm{ZnO}$ films at different deposition rates.

TABLE 1. Recapitulating measured values of Bragg angle (20), the interplanar spacing $(d)$, the full width at half-maximum (FWHM), the crystallite size $(G)$, and lattice parameters ( $c$ and $a$ ) for thin $\mathrm{ZnO}$ films as a function of deposition rate.

\begin{tabular}{c|c|c|c|c|c|c|c}
\hline $\begin{array}{c}\text { Deposition } \\
\text { rate, } \mathrm{ml}\end{array}$ & $h k l$ & $2 \theta$, degree & $d, \AA$ & $\begin{array}{c}\text { FWHM, } \\
\text { degree }\end{array}$ & $G, \mathrm{~nm}$ & $c, \AA$ & $a, \AA$ \\
\hline 07 & 002 & 33.89 & 2.64461 & 0.62 & 12.26 & 5.28922 & 3.305192 \\
11 & 002 & 33.75 & 2.65528 & 0.32 & 23.43 & 5.31056 & 3.232482 \\
13 & 002 & 34.01 & 2.63565 & 0.45 & 16.72 & 5.2713 & 3.326635 \\
\hline
\end{tabular}


polycrystalline in nature with a hexagonal wurtzite-type structure (JCPDS card no. 036-1451) [13]. The XRD patterns of all the samples indicated increased intensities for the peaks due to the increasing in thickness or the quantity of precursors deposed [14]. As can be seen, the (002) plane indicates preferential orientation along the $c$-axis. The full width at half-maximum (FWHM), $\beta$, of thin $\mathrm{ZnO}$ films for (002) plane is given in Table 1. As the thickness increases, FWHM of thin films shows an increase and then decrease. The lattice parameters ' $a$ ' and ' $c$ ' were calculated using the lattice spacing $\left(d_{h k l}\right)$ of (002) plane and the following relation [15]:

$$
d_{h k l}=\left(\frac{4}{3} \frac{h^{2}+h k+k^{2}}{a^{2}}+\frac{l^{2}}{c^{2}}\right)^{-\frac{1}{2}} .
$$

The crystallite size of thin $\mathrm{ZnO}$ films $(G)$ was calculated using a well-known Scherrer's formula [16]:

$$
G=\frac{0.9 \lambda}{\beta \cos \theta},
$$

where $\lambda$ is the x-ray wavelength (of $1.5406 \AA$ ), $\beta$ is the observed angular width at half-maximum intensity (FWHM) of the peak, and $\theta$ is the Bragg's angle.

Figure 3 shows the variation of crystallite size as a function of deposition rate; it can be observed in Fig. 3 that the crystallite size increases until reaching the value of $23.43 \mathrm{~nm}$, which corresponds to the deposition rate of $11 \mathrm{ml}$ indicating by an improvement in the

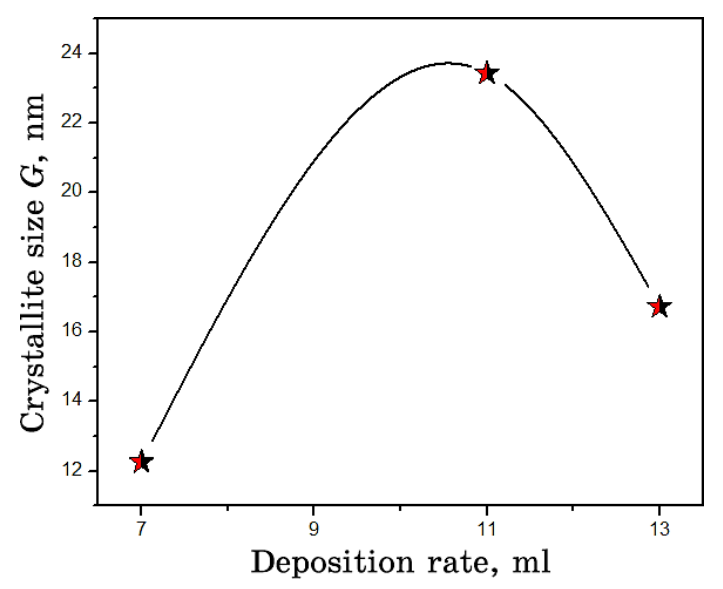

Fig. 3. The variation of crystallite size as a function of deposition rate for thin $\mathrm{ZnO}$ films. 
crystallinity [17], then deceases that provides an adequate explanation for the deterioration in the crystallinity of the films. The $c$ axis strain $\left(\varepsilon_{z z}\right)$ values have been calculated using the following equation [18]:

$$
\varepsilon=\frac{c-c_{0}}{c_{0}} \cdot 100 \%,
$$

where $c$ is the lattice parameter of the thin films calculated from the x-ray diffraction data, and $c_{0}$ is the lattice parameter of bulk $\mathrm{ZnO}$ (standard $c_{0}=0.5206 \mathrm{~nm}$ ). Table 1 gives the variation of values of Bragg angle $(2 \theta)$, the interplanar spacing $(d)$, the full width at half-maximum (FWHM), the crystallite size $(G)$, and lattice parameters $(c$ and $a$ ) for thin $\mathrm{ZnO}$ films as a function of deposition rate.

\subsection{Optical Properties of Thin ZnO Films}

The impact of deposition rate on the optical transmittance of the $\mathrm{ZnO}$ samples is shown in Fig. 4. As the thickness increases and, therefore, the deposition time increases, the transmittance of films decreases; this result was expected, as the deposition time is increased, the absorbance of photons in a material increases. Additionally, the roughness is proportional to the thickness that provides increasing in multiple internal reflections at the surface and gives an adequate explanation for the decreasing in transparency level [14].

For further study of the effect of deposition rate on optical proprieties of thin $\mathrm{ZnO}$ films prepared by solar spray pyrolysis, we use the transmission spectra recorded within the $300-900 \mathrm{~nm}$ wavelength region to calculate band gap energy $\left(E_{g}\right)$ and Urbach energy $\left(E_{u}\right)$.

The $E_{g}$ value is calculated by means of the Tauc plot and using the following relation [19]:

$$
(A h v)^{2}=C\left(h v-E_{g}\right),
$$

where $A$ is the absorbance, $C$ is a constant, $h v$ is the photon energy, and $E_{g}$ is the band gap energy of the thin films. Figure 5 shows a variation of $(A h v)^{2}$ as a function of $(h v)$ used to inferring optical band gap $E_{g}$. The Urbach tail energy $\left(E_{u}\right)$ is expressed from the following relation [20]:

$$
A=A_{0} \exp \left(h v / E_{u}\right),
$$

where $A_{0}$ is a constant, $h v$ is the photon energy, and $E_{u}$ is the Ur- 


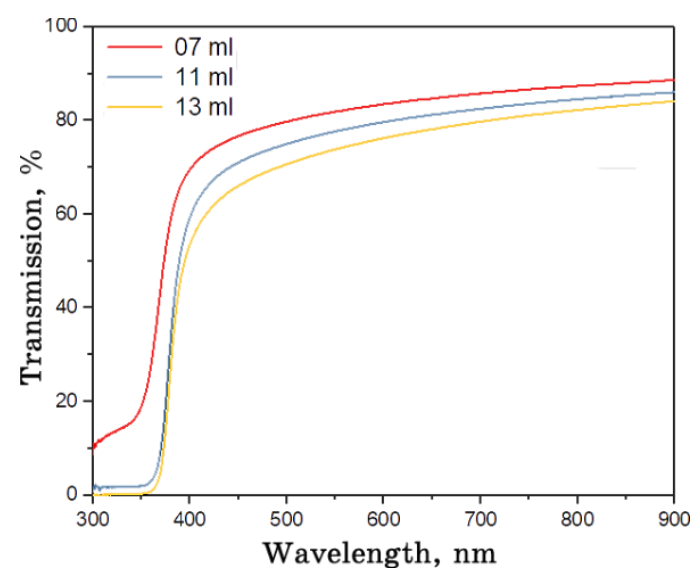

Fig. 4. Transmission spectra $T(\lambda)$ of thin $\mathrm{ZnO}$ films for different deposition rates.

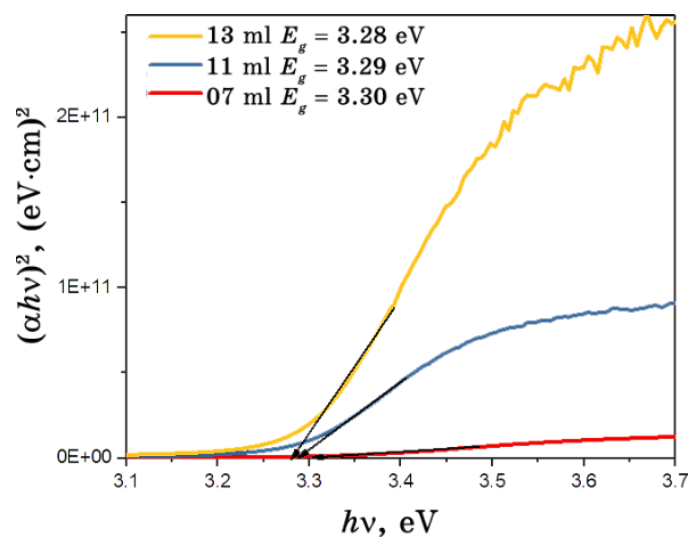

Fig. 5. The typical variation of $(A h v)^{2} v s$. photon energy for all deposited thin $\mathrm{ZnO}$ films as a function of deposition rate.

bach energy. The values of $E_{g}$ and $E_{u}$ are mentioned in Table 2. As it can be seen in Fig. 6 , the $E_{g}$ values estimated decrease slightly from 3.30 to $3.28 \mathrm{eV}$. In contrast, the $E_{u}$ values increase with the thickness. This is due to disorder in the film [21].

\subsection{The Electrical Resistivity of Thin ZnO Films}

The electrical resistivity was measured by the Keithley electrometer 2400 using the four-probe method with a closer temperature, where a constant current is applied to the films and the different voltages are concluded. Figure 7 shows the variation of the electrical resis- 




Fig. 6. The variations of optical band gap $E_{g}$ and Urbach energy $E_{u}$ for thin $\mathrm{ZnO}$ films with deposition rate.

TABLE 2. Recapitulating measured values of band gap energy $\left(E_{g}\right)$, Urbach energy $\left(E_{u}\right)$, and electrical resistivity $(\rho)$ for thin $\mathrm{ZnO}$ films as functions of deposition rate.

\begin{tabular}{c|c|c|c}
\hline Deposition rate, $\mathrm{ml}$ & $E_{g}, \mathrm{eV}$ & $E_{u}, \mathrm{meV}$ & $\rho, \Omega \cdot \mathrm{cm}$ \\
\hline 07 & 3.30 & 123.2 & 1.19 \\
11 & 3.29 & 145.6 & 0.01 \\
13 & 3.28 & 190.0 & 0.08 \\
\hline
\end{tabular}

tivity $\rho$ of $\mathrm{ZnO}$ at different deposition rates; it can be observed that the resistivity decreases from 1.19 to $0.01 \Omega \cdot \mathrm{cm}$ with the deposition rate increasing from 7 to $11 \mathrm{ml}$; then the resistivity slightly increases reaching $0.08 \Omega \cdot \mathrm{cm}$ as the deposition rate increases to $13 \mathrm{ml}$. The decrease of resistivity from 1.19 to $0.01 \Omega \cdot \mathrm{cm}$ can be explained by the improvement in the crystallite size that causes the decrease in grain-boundary scattering [14]. As for the increase in resistivity, this is due to deterioration of the crystallinity.

\section{CONCLUSIONS}

In the present study, solar spray deposition method was used to fabricate $\mathrm{ZnO}$ films for different thicknesses (7, 11 and $13 \mathrm{ml})$. The impact of deposition rate on the structural, optical, and electrical properties is studied and found to be influenced. The XRD results show that the films are polycrystalline of the hexagonal wurtzite type, and the (002) plan was preferred orientation. The crystallite size increases until it reaches $23.43 \mathrm{~nm}$ and then decreases to 16.72 


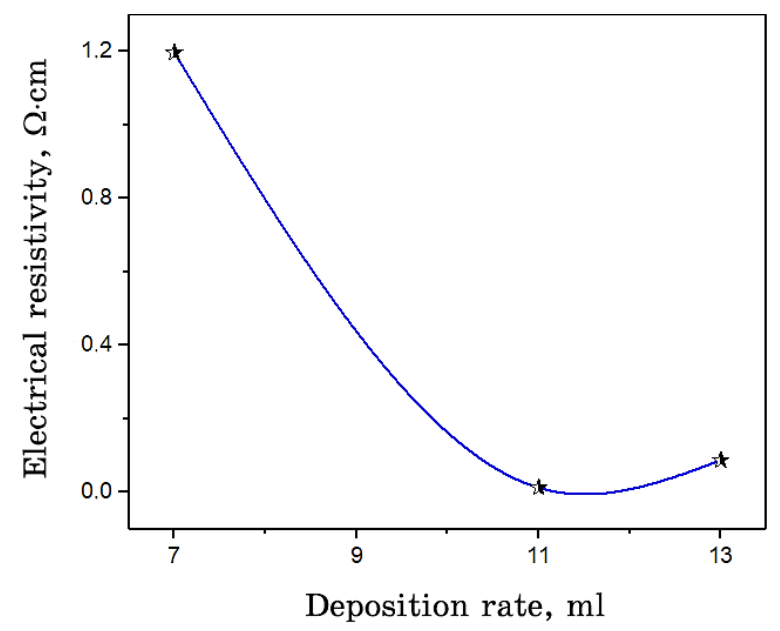

Fig. 7. Electrical resistivity of thin $\mathrm{ZnO}$ films at different deposition rates.

$\mathrm{nm}$ perhaps due to crystallinity case. Optical proprieties show that the transmittance decreases when the deposition time increases, and, with increasing of the film thickness, the values of band gap energy and Urbach energy change oppositely. The smallest recorded value of $E_{g}$ is of $3.28 \mathrm{eV}$, whereas the Urbach energy is of 190.0 $\mathrm{meV}$, and the deposition rate corresponds $13 \mathrm{ml}$. The low result of the electrical resistivity $(0.01 \Omega \cdot \mathrm{cm})$ is achieved at highest value of crystallite size.

\section{REFERENCES}

1. K. Davis, R. Yarbrough, M. Froeschle, J. White, and H. Rathnayake, RSC advances, 9: 14638 (2019).

2. S. K. Sahoo, C. A. Gupta, and U. P. Singh, Journal of Materials Science: Materials in Electronics, 27: 7161 (2016).

3. T. Logu, P. Soundarrajan, D. Naveena, K. Sankarasubramanian, S. S. Kumar, and K. Sethuraman, Solar Energy, 177: 108 (2019).

4. E. Karimi and S. M. B. Ghorashi, Journal of Electronic Materials, 49: 364 (2020).

5. S. Benramache, Annals of West University of Timisoara - Physics, 61, Iss. 1: 64 (2019); DOI: 10.2478/awutp-2019-0006

6. H. Belkhalfa, H. Ayed, A. Hafdallah, M. Aida, and R. T. Ighil, Optik, 127: 2336 (2016).

7. S. Benramache, Y. Aoun, A. Charef, B. Benhaoua, and S. Lakel, Inorganic and Nano-Metal Chemistry, 49: 177 (2019).

8. A. A. Ramirez, I. Gil, G. Gordillo, and A. M. Latifi, Thin Solid Films, 698: 137846 (2020).

9. M. H. Suhail, I. K. Adehmash, S. M. A. Kareem, D. A. Tahir, and 
O. G. Abdullah, Transactions on Electrical and Electronic Materials, 21: 355 (2020); https://doi.org/10.1007/s42341-020-00182-3

10. S. Saini, P. Mele, T. Oyake, J. Shiomi, J.-P. Niemelä, M. Karppinen et al., Thin Solid Films, 685: 180 (2019).

11. Y. Aoun, R. Meneceur, S. Benramache, and B. Maaoui, Physics of the Solid State, 62: 131 (2020).

12. E. Andrade and M. Miki-Yoshida, Thin Solid Films, 350: 192 (1999).

13. K. Sandeep, S. Bhat, P. Kumar, S. R. Maidur, F. J. Serrao, and S. Dharmaprakash, Physica E: Low-Dimensional Systems and Nanostructures, 107: 47 (2019).

14. T. P. Rao and M. Santhoshkumar, Applied Surface Science, 255: 4579 (2009).

15. O. Bazta, A. Urbieta, J. Piqueras, P. Fernández, M. Addou, J. Calvino et al., Ceramics International, 45: 6842 (2019).

16. S. Susilawati, A. Doyan, L. Muliyadi, and S. Hakim, Jurnal Penelitian Pendidikan IPA, 6: 1 (2020).

17. F. Khediri, A. Hafdallah, and M. Bouhelal, Defect and Diffusion Forum, 397: 81 (2019); https://doi.org/10.4028/www.scientific.net/ddf.397.81

18. K. Salim, M. Medles, A. Nakrela, R. Miloua, A. Bouzidi, and R. Desfeux, Optik, 210: 164504 (2020) ; https://doi.org/10.1016/j.ijleo.2020.164504

19. A. K. Ambedkar, M. Singh, V. Kumar, V. Kumar, B. P. Singh, A. Kumar, and Yo. K. Gautam, Surfaces and Interfaces, 19: 100504 (2020); https://doi.org/10.1016/j.surfin.2020.100504

20. A. R. Hegazy, B. Salameh, M. Mathai, and A. Alsmadi, Ceramics International, 46, Iss. 9: 13151 (2020); https://doi.org/10.1016/j.ceramint.2020.02.089

21. S. Benramache, Y. Aoun, S. Lakel, and B. Benhaoua, Materials Research Express, 6: 126418 (2019). 